\title{
THE ACTIVITIES OF THE UNITED NATIONS FOR THE RIGHT TO EDUCATION FOR INDIGENOUS CHILDREN
}

\author{
Anita Rakhman \\ Postgraduate at the International Law Department of the Law Institute, RUDN University, Russia, \\ 1042190143@pfur.ru
}

\begin{abstract}
The concept of protecting human rights, such as the right to education, has become a centerpiece for the international law system. Particularly, ensuring indigenous peoples' rights has increased attention at the universal, regional, and national levels. The protection of the rights of indigenous children as a vulnerable category of the world population is complex due to climate change, forced displacement, economic exclusion, exploitation, or armed conflict. It is evident that adequate realization of the right to education depends on access to health services, self-determination, and cultural identity, protection from exploitation, abuse, discrimination, and violence.

As indigenous peoples are the custodians of unique knowledge and rare languages, which are significant elements of humanity's heritage, the educational process for their children must include specified educational methodologies and other features. So various international and regional mechanisms have been established to promote and protect indigenous children's right to education and other fundamental freedoms.

The article is concerned with the United Nations (UN) activities for ensuring indigenous children's right to education according to the international human rights protection system. The investigation describes international legal standards and the UN's programs and strategies for aboriginal and tribal peoples from different continents to increase the percentage of educated and competent indigenous children and young people and their results. The UN's framework contains specific methods, skills, tools, and rules. There is significant progress in the rise of educational levels among indigenous peoples.

The article can be helpful for those who are searching for new positive methods of educating various categories of children in different countries. It contains specific information about the educational process for ethnic minorities.
\end{abstract}

Keywords: Aboriginal children, Indigenous people, United Nations, right to education.

\section{INTRODUCTION}

The United Nations Organization is of colossal importance in such vital areas as sustaining international peace and security, developing global cooperation, and promoting the peaceful resolution of conflicts. According to many lawyers, human rights are the starting point for realizing its goals. The UN possesses a wide range of various mechanisms aimed both at ensuring them in general and at promoting individual rights for specific groups of people: women, children, people with disabilities, migrant workers, representatives of the indigenous population.

Indigenous peoples, being vulnerable and, unfortunately, even oppressed category of the world's population, need support from the world community and international law. Aboriginal children find themselves in a challenging situation, the exercise of whose fundamental rights is insufficiently effective.

The UN Commission on Human Rights points out that in many countries, indigenous children, in particular girls, 
experience difficulties in obtaining full access to educational services. Moreover, when they do, their education is generally of more inferior quality than that of non-indigenous populations. The Special Rapporteur emphasized that the difficulties encountered by indigenous children are a matter of concern, in particular the difficulties arising from discrimination based on ethnicity and gender, the latter often being compounded by gender discrimination prevailing within the indigenous communities themselves.

In this regard, this paper considers the UN activities to implement the right of indigenous children to education, in particular, the documents and measures taken by UNICEF, UNESCO, OHCHR, the Working Group on Indigenous Affairs, as well as strategies until 2030 within the framework of achieving the Sustainable Development Goals.

\section{METHODOLOGY}

The methodological basis of the study involves a combination of general scientific (dialectical, historical, inductive, deductive, analytical, synthetic) and private, scientific methods (formal-legal, comparative-legal, interpretative, statistical, procedural, and dynamic).

Firstly, the study analyzed several universal legal acts on human rights and the rights of indigenous peoples, and secondly, documents, programs, strategies adopted within the UN and its specialized agencies.

The right to education is enshrined in fundamental human rights instruments such as the Universal Declaration of Human Rights (Art.26), International Covenant on Economic, Social and Cultural Rights (Art.13 and 14), Convention on the Elimination of All Forms of Discrimination against Women (Art.10), Convention on the Rights of the Child (Art.28 and 29). At the regional level, it is reflected in the European Convention on Human Rights and Fundamental Freedoms (Art. 2 of Protocol No. 1), the American Convention on Human Rights (Art. 13 of the Additional Protocol), the African Charter on Human and Peoples' Rights (Art.17). It is proof of the indisputable importance of education for every child, without discrimination on any grounds.

It is important to note that the right to education includes some aspects that are significant for the indigenous population: free, compulsory primary and affordable secondary education, equal access to higher education, the freedom of parents to choose educational institutions for their children according to religious and moral beliefs, the freedom to create educational institutions and run them following the minimum standards set by the state. These components play an essential role for indigenous peoples, who are so due to their commitment to traditional culture and identity.

The UN Declaration on the Rights of Indigenous Peoples is currently the only comprehensive document to protect their rights. It contains the following provisions:

1. Indigenous peoples have the right to establish and control their educational systems and institutions, providing education in their languages in a manner appropriate to their cultural methods of teaching and learning (art. 14);

2. Indigenous peoples have the right to the dignity and diversity of their cultures, traditions, histories, and aspirations, which shall be appropriately reflected in education and public information (art. 15);

3. States shall, in consultation and cooperation with indigenous peoples, take specific measures to protect indigenous children from economic exploitation and from performing any work that is likely to be harmful to the child's health or physical, mental, spiritual, moral, or social development, taking into account their particular vulnerability and the importance of education for their empowerment (art. 17);

4. Indigenous peoples have the right, without discrimination, to improve their economic and social conditions in the areas of education, employment, vocational training and retraining, housing, sanitation, health, and social security (art. 21).

\section{RESULTS}

UNICEF's work is divided into several areas, corresponding to aspects of children's lives essential for their well-being. Of course, we can find the aspect related to education:

1. Every child must learn. The Organization implements measures to support national authorities in providing quality education to Aboriginal children. For example, the 2015-2018 program provided to the governments of Cambodia and Myanmar, consisting of many ethnocultural events, contributed to the popularization of the culture of indigenous tribes, the publication of 25 children's books in the languages of indigenous communities with a circulation of 415,000 copies. In 7 states of Myanmar, 20,000 primary school children got 
the opportunity to work with textbooks in their native language. In 2019, UNICEF developed a bilingual education model for the education system in 3 regions of Peru, taking full responsibility for all technical equipment. As part of the campaign, bilingual round tables were regularly held with representatives of the indigenous population of various professions (writers, philologists, and others), which created many bilingual education programs in these areas.

2. All children are equal, and each of them has the right to life. To reduce as much as possible the number of indigenous children living below the poverty line and, therefore, lacking adequate social and economic conditions to lead a meaningful life, UNICEF is developing recommendations for national governments. For example, an Alternative Learning System program was implemented in one of the Philippine provinces, in which 130 volunteers were trained to educate Aboriginal children who had no access to school. According to this model, about 2,700 children have received an education because they have acquired scientific, social, household, and other skills. In 2019, on the recommendation of the Organization and the support of the state government, 39,102 indigenous teenagers in Brazil were able to receive special training with a political and legal bias to be able to participate in the country's activities in the future, defending the rights of indigenous people.

Moreover, on the $7^{\text {th }}$ of April 2020, due to the COVID-19 pandemic, UNICEF has launched a global MultiReligious Faith-in-Action COVID-19 Initiative to raise awareness of the impacts of this pandemic on the world's youngest citizens. The Initiative reflects the unique and critical roles of religious leaders and actors in influencing values, attitudes, behaviors, and actions that affect the development and well-being of the world's children. It commits to strengthening multi-religious action and calls upon all communities worldwide, together with governments, UN entities, and broad civil society organizations. The initiative is aimed to stand united in this global Interfaith moment of hope and solidarity for the survival, protection, and development of our children, families, and communities.

UNESCO implements long-term programs to support indigenous children's education in the Philippines, Australia, Bolivia, Mexico, USA, Nepal, Morocco, Guatemala, New Zealand.

The Organization implements several multimedia programs to educate indigenous peoples' children using traditional cultural elements to preserve it for the younger generations. For example, there are already digital lessons on the history and skills of canoeing for children of the indigenous peoples of Polynesia, the use and maintenance of the sustainability of forest ecosystems for the children of the Marovo people in the Solomon Islands, the preservation of the biosphere for the children of the Majagna people from Nicaragua, the traditional handling of natural resources for aborigine children of Vanuatu and Canada.

In 2011, the ICT and Indigenous Peoples program was launched and is now being successfully implemented to create appropriate conditions for using ICTs by indigenous peoples to support their native language, culture, and traditional knowledge. In some countries, for example, in the United States, educational platforms have already been created, thanks to which indigenous communities have the opportunity to control curricula, staffing independently, means, and learning strategies within their educational programs.

Overall, as highlighted in the 2017 Guide to Inclusiveness and Equality in Education, the 21st century has seen significant progress towards realizing the right to quality education. However, there are still 263 million children aged 6-17, of which the lion's share is occupied by indigenous children who do not have the opportunity to attend school. Therefore, one of UNESCO's essential areas is combating marginalization and inequality within indigenous communities, linguistic and ethnic minorities.

UNESCO International Institute for Higher Education in Latin America and the Caribbean was established as part of UNESCO's Education Program to assist countries in tackling challenges related to the internationalization of higher education. Its main objectives are:

1. To strengthen cooperation among member states in the field of higher education;

2. Contribute to the renewal of higher education in the region and improvement in reciprocal knowledge of tertiary education systems;

3. Achieve better utilization of human and educational resources by promoting greater mobility of professionals in higher education systems;

4. Act as a clearinghouse and reference center supporting member states and institutions in improving higher education.

The Working Group on Indigenous Affairs is actively working with national governments in various areas of Aboriginal rights, and this cooperation is fruitful. For example, with its support, for Nunavut (Canada) and 
Zapatista (Mexico) indigenous communities, their autonomous education systems were formed concerning national and traditional characteristics. Teachers who also belonged to these communities developed educational programs adapted for local children; volunteers conducted pedagogical training and master classes for six months. The Mexico City government even facilitated the construction of a school in the city.

With the assistance of $\mathrm{OHCHR}$, state laws are being improved and brought closer to international human rights standards. Thus, the Danish Law on the Greenlandic language recognizes it as an official language on the territory of Greenland and determines that it can be used in official affairs on an equal basis with Danish. Local governments should ensure that local children receive instruction in Danish and other languages to enable Greenlandic youth to continue their education in Denmark and other countries.

Also, since 2000 the Ethiopian government, under the auspices of OHCHR and with the support of IFAD, has established several federal, regional, and local institutions that deal with cultural issues. One such institution is the Academy of Ethiopian Languages, which aims to develop the languages existing in the country for their use in education and protect them from extinction. In addition, activities such as the designation of culturally and biodiversity important sites on official maps are encouraged.

Speaking about the everyday activities of the UN, it is not advisory forget the Sustainable Development Goals until 2030, which are a roadmap not only for the Organization itself but also for each state of the world individually.

The SDGs explicitly include indigenous peoples. One of the SDGs (Goal 4: «Qualified education») makes specific references to indigenous peoples, committing to double the agricultural output of indigenous smallscale farmers and ensuring equal access to indigenous children's education. There is also a strong commitment

to empower and engage indigenous peoples in implementing and reviewing progress in achieving the goals.

Social Security, health, and education are the most potent elements related to social development, including securing access to health, education, and social protection with the explicit goal of reaching the most vulnerable. To overcome discrimination against indigenous peoples, who are overrepresented amongst the vulnerable, poor, illiterate and unemployed, additional efforts are needed to provide social services and more broadly in the public sphere. These should follow a rights-based and culture-sensitive approach, which respects language diversity, education in the mother tongue, traditional health practices, and indigenous medicine.

Further, it is essential to strengthen and support indigenous peoples' methods of providing these services.

\section{DISCUSSIONS}

Many international human rights law experts argue that the UN are indeed making serious efforts to improve the living standards of Aboriginal children. Organizations, through a variety of strategies and programs, as well as financial support measures, give children the opportunity to try to realize their potential in different areas while focusing on acute global problems that affect their well-being and the communities where they live: climate change, human trafficking, sexual slavery, forced displacement, extreme poverty, and others.

\section{ACKNOWLEDGEMENT}

This article has been prepared under the RUDN university 5-100 program.

\section{REFERENCE LIST}

Medium-term strategy for 2014-2021. (2014) UNESCO. France. URL: https://unesdoc.unesco.org/ark:/48223/pf0000227860_rus

UNESCO Policy on Engaging with Indigenous Peoples. (2018) UNESCO. URL: https://unesdoc.unesco.org/ark:/48223/pf0000262748

Salaman Declaration and Framework for Action on Education for Persons with Special Needs. (1994) UNESCO. URL: https://unesdoc.unesco.org/ark:/48223/pf0000098427_rus

Guidelines for Inclusive Education. (2009) UNESCO. URL: https://docplayer.ru/27371659Rukovodyashchieprincipy-politiki-v-oblasti-inklyuzivnogo-obrazovaniya.html 
UNESCO. Official website. URL: http://www.unesco.org/new/en/naturalsciences/priorityareas/links/knowledge-transmission / A Guide for ensuring inclusion and equity in education. UNESCO. 2017. URL: https://unesdoc.unesco.org/ark:/48223/pf0000248254

UNICEF. Official website. URL: https://www.unicef.org/what-we-do

Global Annual Results Reports 2019. UNESCO. 2020. URL: https://www.unicef.org/reports/global annualresults-2019

Report of the Special Rapporteur on indigenous peoples to the Commission on Human Rights. (2014). OHCHR. URL:

https://documents-dds-ny.un.org/doc/UNDOC/GEN/G14/179/09/PDF/G1417909.pdf?OpenElement

Human Rights. A Basic Handbook for the UN staff. (2018) OHCHR. URL: https://www.ohchr.org/documents/publications/hrhandbooken.pdf

Briefing Note. Indigenous Peoples' Rights and the 2030 Agenda. (2017) OHCHR. URL: https://www.ohchr.org/Documents/lssues/IPeoples/BriefingPaperIPRights2030Agenda.pdf 